\title{
Bondage of Time and Human Bondage in Anita Desai's Clear Light of Day
}

\section{Srabani Mallik}

Assistant Professor of English, Institute of Modern Languages, University of Chittagong, Bangladesh

\begin{abstract}
The aliveness of nonexistent persons and their associations to those who exist are the themes that are dealt with in Anita Desai's Clear Light of Day. The present study endeavours to pass through the consequences of time in the spheres of familiar and familial life. The history of the nation puts a collateral impact on the story of the characters of the novel. In Clear Light of Day, it is pictured that the Partition Movement and communal rioting of the nation coincidentally dissipate the Das family. The only person who has stayed home is Bim who has nursed her memories and grudges, but who had been left behind by all who chose the exit doors and ultimately, she lets go of her resentments by finding the strength of bondage in herself for her siblings and relatives. Her house is the embodiment of kinship and love and she fosters this sort of appreciation all through her life in a metaphorical way. Eventually, time as a preserver emerges as triumphant and time as a destroyer is pushed into the background. Time, the Preserver, unites the family and the essential bonding of the members persists finally.
\end{abstract}

Keywords - Time, Relationship, Memory, Destroyer, Preserver.

\section{INTRODUCTION}

In the domain of Indo-Anglican fiction, Anita Desai's Clear Light of Day may be regarded as one of the masterpieces and it is one of the most unparalleled novels of her. This novel superbly focuses on providing the messages of psychological analysis of indestructible ties of blood and kinship and the paradox of time i.e. time as a destroyer as well as a preserver. The setting of Clear Light of Day is in India's Old Delhi and Desai deals with family scars, the ability to forgive and forget, and the trials and tribulations of familial love in a very tender, warm, and compassionate way. Anita Desai was born in 1973 to an Indian father and German mother and Desai has spent most of her life in India. She mainly conjectures on the individual psychology of the characters in her work. She accentuated this facet, in an interview with Feroza Jusswalla: "If they were simply representatives, they would be like cardboard creatures; they would be posters rather than paintings. They would simply stand for a certain society or a certain moment in history, which of course they don't"' (O' Reilly 26).

The members of the Das family have grown apart from each other and the moving relationships between the members of the Das family are at the novel's heart. For example, Raja is one of the central subjects in Delhi though he lives in Hyderabad, Aunt Mira's presence in Tara's as well as Bim's memories of the house, its past and present character and atmosphere despite her death. The novel is about a solemn song of praise for Old and New Delhi, the city that is the embodiment of both ancient and modern times; it is a sombre song of a city that has witnessed the Muslim and British empires' build and collapse. Delhi is that city that is compromising tradition with change, whose essential life continues with its own pace, and it is also signified in this novel how this city is welcoming diversity to unity and is keeping alive its intrinsic relation to those who still live in it or have fallen away. Bimla who lives in her childhood home, where she cares for her mentally challenged brother, Baba. She is a discontented but determined teacher at a women's college and her younger sister, Tara is unambitious, estranged who is married and has children of her own. Both Bim and Tara have another younger brother, Raja who is popular, brilliant as well as successful. It is pictured here that old memories and tensions resurface and blend into a domestic drama when Tara returns for a visit with Bimla and Baba and the recollections of the old days and the subsequent results are intensely striking that ultimately lead to insightful selfunderstanding. 


\section{DISCUSSION}

Anita Desai in Clear Light of Day cites lines from two poems by Emily Dickinson and T. S. Eliot as inscriptions to the novel. The initial epigraph has the following lines of Emily Dickinson:

\section{Memory is a strange bell- \\ Jubilee and knell-}

These two lines signify that in the novel, memories of the past play an essential role and both memories and past are juxtaposed with the present as indicated in the endorsements " Memories of the past coalesce with the tensions and jealousies of the present in this sharply drawn an sorrowful portrait of the ebb and flow of sisterly love." Memory of the bondages of human relationship plays even a very vital role in the context of their autistic brother Baba who is increasingly unquiet and in his mind, there are certain impressions that keep recurring. Baba cannot go beyond those thoughts because of his limited mental enactments.

Desai has quoted the second inscription from a poem by T.S. Eliot that describes the passage of time and how things do not change reality despite the passing of time, only the pattern changes:

See, now they vanish,

The faces and places, with the self which, as it could, loved them,

To become renewed, transfigured, in another pattern.

Anita Desai has said that time plays a crucial part in the novel and at the end of the novel, there is a quotation from T.S. Eliot's Four Quarters: "Time the destroyer is time the preserver". More or less, this line fortifies the thought suggested in Eliot's quotation in the epigraph.

Nowadays, uncertainty, dissatisfaction and total rootlessness are increasing because of the growth of technology, the expansion of communication, the varying family patterns, diverse social, political and economic state of affairs of the contemporary man. Desai deals with these concepts with an entire visualization of human life. The concept of alienation and rootlessness are common among Indians irrespective of their status in the society, unfortunately, Anita Desai's protagonists seem to undergo sociological alienation in the beginning; in the end, they experience lacking of bondage among themselves.

Desai sets off the story at a point when Tara and her diplomat husband are coming to visit home after a time that passes away from all the family members. When Tara comes back home, she becomes totally astonished that in her home, nothing has changed; she shares her observations to her sister Bim:

Tara: Now everything goes on and on here and never changes. I used to think about it all and it is all the same, whenever we come home.

Bim: But you would not want to return to life as it used to be, would you? All that dullness, boredom waiting, would you care to live that over again? Of course not. Do you know anyone who would secretly, sincerely in his innermost self, really prefer to return to childhood? (P.-6)

In this regard, we can compare Desai's Clear Light of Day with W. Somerset Maugham's Of Human Bondage. Maugham's Of Human Bondage concerns with varieties of personal bondage. Through Philip's travail, we see he suffers from the bondage of passion, of religious belief and emotional dilemmas, etc. Philip gradually frees himself from the bondage of religion, passion, class-prejudice, art, ambition, economic dependence, and the natural human desire to discover meaning and order in the universe. The revelation of life philosophy through his pilgrimage gives the enlightenment: one can overcome his weak points and surpass human bondages by exerting his will and reason.

Like Maugham's Of Human Bondage's protagonist Philip's spiritual struggles, doubts, search for truth and meaning, disillusions, and final attainment of a philosophy of life that releases him from the most galling shackles of his human bondage, Desai's Clear Light of Day strikes a significant chord of a desire of the protagonist(s) to revive her/their primary self/selves. We observe that the passage of time has brought a change in all the characters' circumstantial reality that a shift occurs in their materialistic roles and this same sort of experience is manifested in their physical displacement from their old 'home' to new places contextualizing Tara and Raja. The two major protagonists of the novel namely Bimla and Tara turn out to be the carriers of subtle signification wherein the dynamics of duality can be traced with a compelling craving to come back to the most important nature of realization with special indication to the disposition of Bimla. Both of them experience chaos and misery only because of their desired 'being'. Now they wish to harbour a solace in returning to their prime self that connotes a condition of harmony and serenity in their beings.

Bim tries to surge to go deep of her thoughts of her own relational situationally with relation to understanding and re-understanding the relationships. The existential gaps to be filled are preferred and that can indeed be found in her psychic agony as uncovered by the sequence of events. 
The narrative also brings forth about her being of holding responsibility as well as of fulfilling the quoted desirability in the later rejuvenation and re-negotiation. At the end of the storyline, Bim experiences the clear light of day wherein all the dualities disintegrate and are negotiated resulting in the exchange of emptiness into meaningfulness.

The setting of the novel is typical as per Desai's fictional world view and it also upholds bondage of time and the relationships. It is an old home in old Delhi which is counter-pointed to New Delhi. Shifting from the depiction of the old house symbolizing boredom, meaninglessness, pathos and decay, the inmates further enhance the thematic impact of negativity and passivity wherein absence of mutual love is strongly foregrounded. It appears that the house is always been like this, with its overgrown bushes and undernourished flowers, stultifying and strangling human life, and people either die or abandon it(Jain: 417). The parents have been depicted as the carriers of unconcern signifying mechanical relationship with their children.

In Desai's Clear Light of Day, time plays a vital role and it delineates time as a force which is a destroyer at the same time a preserver. With great success the author has brought out a deep truth underlying the paradox that time is a destroyer, should also be regarded as a preserver. This duality of time - time as a destroyer as well as a preserver- has been intensely pictured by the author in her novel.

It is needless to say that Anita Desai has culled the concept of time from eminent modern poet Thomas Stern Eliot who personifies time as the destroyed as well as preserver as Shelley personifies the west wind as the "Destroyer and Preserver". Shelley also views time as a destructive and creative power or god what is vivid in his sonnet Ozymandias and Ode to the West Wind. W.B Yeats in his The Second Coming shows how time destroys one civilization and gives birth to others. Time causes great empires lime Roman, Egyptian, Babylonian etc. flourish and decay at the same time. However, Anita Desai herself opines:

"My novel is about time as a destroyer, as a preserver, and about what the bondage of time does to people. I have tried to tunnel under the mundane surface of domesticity."

It is delineated in Clear Light of Day that the characters are moving in past and present. Desai provides the affirmation that "Time is presented as the fourth dimension of human existence". The novel, in fact, revolves around 'Time'. It is shown that how time plays the role of destroyer and preserver predominantly in the life of the members of the Das family who embody all Indian victims of time and broadly the whole human race who are somewhat affected by time. In Mira-masi's case, we see that how much havoc time can bring in one's life and she certainly experiences it although her life. Time itself brings the catastrophe of her immature marriage as well as the premature death of her husband and it is time that brings the premature death of Masi herself.

Mira-masi's intolerable pressure of suffering and sorrow were brought by the tragic and pathetic time of her life. She wanted to escape from those sufferings and therefore addicted to drug that ultimately took her breath. She also experienced the difficult time of Das family along with her sorrows and pains. It was the transitional period of the Das family when she entered into the family as all the existing family members became helpless after the parents' death. Although the parents were not so joyful in their lifetime for the children, but the existence of them gave the children breath. Now their death or absence turns out to be a challenge for the children and each member of the Das family come to realize their presence in their absence. The absence of parents' shelter brings forth the breakdown of the closest relation of family members particularly of Bim and Raja within a short period of time. It is time that makes Raja adamant to leave beloved parents' family for Hyderabad and Bim becomes hurtful and frustrated. She faces a lot of difficulties in handling the family as a woman and it shows how Raja's absence destroys the remaining happy atmosphere of Das family. In terms of familial or brother-sister relation, the recurrent time is more disparaging and the humiliating letter of Raja to Bim demonstrates how the relationships are changed by the gap of time, how most beloved ones are now most hated ones and how their psychological bonding is also shattered. Time again universalizes its nature as a destroyer when we see the precious relation of Das family is now cut into pieces by time. If the parents and the society gave preference to the time of family, the sweetest relations might not be destroyed; but ultimately the family could not get away from the assailment of destructive time.

Time antagonizes the lives of the Das family as a catalyst. Dr Madhusudan Prasad interprets:

The obsessive episodes of their shared past, discussed or remembered with unforgettable sweetness and sourness of Bim and Tara in part one are elaborately depicted being actually enacted in their early life thus properly connecting the apparently sprawling pattern of part one with that of part three and revealing the aesthetic relevance of the episodic repetitiveness in the novel. 
In the novel's second part, Desai portrays the life in Delhi with horrors of riot, suspense, sensation and terrorist activities during the partition in 1947. A novel dimension of deep pathos is added in the novel by the portrait of aunt Mira. She fails in fits twice or thrice and she has been described dreadfully ill with a bizarre type of disease. She is obsessed with the image of a well and her last hysterical fit is symbolic of her mania. Tara is an escapist and she flees from the situation by marrying Bakul; amid the partition and the death of Gandhi, Bim is left alone bearing the total responsibility of Baba.

In the third part of the novel, Raja and Tara are illustrated awaiting the birth of their brother Baba in pre-partition India. Miramasi who is a widow and mistreated by her in-laws is brought in to help with Baba, who is autistic. To return to modern India, it is shown that Tara is confronting Bim over Raja's daughter's wedding and Bim's disillusioned relationship with Raja. When Bim's alienation and resentment fades, she comprehends that family love is irreplaceable and can cover all distresses and wounds. She tells Tara to come back from the wedding and she also discloses that she forgives Raja.

Time has brought tremendous transformation and both Bim and Tara come to realize this fact. Bim, Tara and Raja face a severe identity crisis. Santosh Gupta depicts:

The period that lies in between the growing consciousness and search for individuality of adolescence fails to provide continuity from the early period of childhood to the later stage of adulthood, causing deep psychological trauma and stress.

Tara's obsession with her old days of childhood can be seen in the following lines:

This room had been hers and Bim's when they were girls. It opened on to the same grove of guava's trees that separated the back of the house from the row of servant's quarters. Bright morning sounds of activity come from them, a water tap running, a child crying, a cock crowing, a bicycle bell ringing, but the house was separated from them by the thick screen of low, dusty guava trees in which invisible parrots screamed and quarrelled over the fruit. Now and then, one fell to the ground. Tara could see some line in the dust which chunks bitten out by the parrots (P.-11).

The vision of the childhood dominates the novel. The contrast between past and present time, between childhood and adulthood, is crucial to the aesthetic get-up of the characters of the novel. The children of the novel are alienated from the external world that intrudes upon their consciousness and also breeds anguish in their unruffled existence. Tara is not able to recognize the power of time; she is unable to be acquainted with time's existentialist significance as the destroyer, and how time brings changes in human life. She becomes astonished at the changed attitude of Bim towards her brother, Raja with whom she had a very sweet and adorable relationship. Tara's realization of Bim's sufferings, her dedication for others and self-sacrifice intensify Tara's feeling of loneliness. Tara regrets and yearns for her childhood days, but all in vain. She contemplates:

Although it was shadowy and dark...she felt only love and yearning for them all, and if there were hurts, these gashes and wounds in here side that bled, then it was only because her love was imperfect and did not encompass them thoroughly enough, and because it had flows and inadequacies and did not extend to all equally (P.$165)$.

The national life of India is also in turmoil by the uproar of time. India got independence from the British by shedding a cost of blood and the British separated India based on religion that led to the separation of beloved ones, loss of numerous lives of human beings, loss of properties, relatives. The hard and harsh truth is highlighted by Desai that how the Indians once lived in a house irrespective of their religious views and identities and how time has made them eternal enemies now. Hyder Ali is the embodiment of Indian Muslims who moved from place to place for secured living and lost everything being the victim of the wrath of Hindus. The summer of 1947 is the time that became, therefore, haunting for Muslims as a demolisher of their lives and relationships.

In the life of the family as in the life of the country, 1947 is the crucial year. The three houses in Old Delhi: Bim's house, the Misra's, and the Hyder Ali Sahib's figure in the lives of these characters contain three distinctive life cycles and are set up as contrasts to one another. They all appear empty and dreary over time and some of them who then inhabited these houses are still there, though many have disappeared, either by death or by moving to another place. The following passage, beyond specific life and incident, pictures the central theme of the novel:

Who is the third who walks always beside you?

When I count, there are only you and I together

But when I look ahead up the white road

There is always another one walking beside you

Gliding wrapt in a brown mantle, hooded

I do not know whether a man or a woman

---But who is the on the other side of you? 
The passage from the last section of T.S. Eliot's 1922 poem The Waste Land, a poem that, according to Eliot, was written as a necessity against a personal crisis, recurs towards the end of Section II in the novel, invoking Eliot's note on the inspiration:

"The ... lines were stimulated by the account of one of the Antarctic expeditions ...: it was related that the party of explorers, at the extremity of their strength, had the constant delusion that there was one more member than could actually be counted."

Both Tara and Bim hold the delusion that Aunt Mira's soul still seems to inhabit the house or garden. She is a missing person but her presence is felt. Though the autistic brother, Baba is physically there but his existence is nothing to amount as he has no responses or activities which may cohere in his own or others' lives; Raja absented himself physically by moving to Hyderabad; the Das father and mother are dead but they were rarely at home and with the children even when they were alive; across the street, Hyder Ali Sahib and his family no longer live in the house; Tara lives in abroad now, though, at present, she is present in the Old Delhi home.

However, the passage of time does not eradicate everything. There are certain indestructible and imperishable things and in course of time, certain things acquire greater weight, validity and an enduring value of time. For instance, ancient Roman culture can be mentioned that still exists and is still regarded as a model to be emulated. Time can be regarded as a preserver in this respect.

In Clear Light of Day, it is shown that time preserves certain positive experiences and values and certain things continue to exist despite the ravages of time. Here Mira-masi's sacrifice can be exemplified who had assiduously been attending upon the mentally retarded child Baba and had been taking relentless pains to keep him cheerful. Along with this, there is Bim's love and affection for Baba and she had told Tara that she would never marry but would look after Baba. And afterwards, Tara had gone away to a foreign country, Mira-masi had died and Raja had left for Hyderabad, but Bim was alone in the house to look after Baba. Then, stimulated by the presence of Tara and Tara's talk, in an introspective mood, Bim begins to think of the blunder done by Raja to her relationship with him by sending the humiliating letter. The dying Emperor Aurangzeb's words moved Bim deeply and supplemented by those words, her meditations and reflections lead her to forgive Raja for his unjustifiable letter. Emperor Aurangzeb had said that he had entered into this universe with nothing at all but he was going away from here with a heavy burden of irreverence on his mind. Bim's heart was calmed by these words of the Emperor and these words brought tears into her eyes. That night by tearing off, she removed the letter which Raja had written to her many years back, and which had hurt her intensely.

In Desai's Clear Light of Day, the philosophy is idealized that time cannot destroy some experiences of a human being. Tara's reminiscence of the earlier period and her guilty feeling of not assisting Bim when she was bitten by a swarm of bees are vivid examples of how time makes the memory everlasting and unforgettable. Other positive and remarkable events are preserved by time, for example, Mira-masi's sacrifices for Das family particularly for Baba, what she did as an ideal and ultimate well-wisher althrough her life till death. Along with this, Bim's sacrifice and struggle for the family living alone in the old house when all the family members are away from her except Baba as a burden upon her helpless shoulder, her love for Baba; Bim preserves all these memories in her mind. The humiliating letter of Raja and what it does to Bim's relationship with him can also be not forgotten by Bim; while talking with Tara about the facts of time, she thinks over this pathetic matter time and again.

The memorable and touchy event of recollection with Tara ultimately led Bim to be compassionate and affectionate to preserve relationship with Raja. The dying Emperor Aurangzeb's words are meditated by Bimla and she forgives all of Raja's ill-treatment with her and eventually reconciles with her beloved brother. Bim comes to realize that there have been flaws with her in terms of her love and concern not only for Raja but for Tara and Baba also. Though she tears off Raja's letter in anger, she gives assurance to Tara with a loving message for Raja from whom she had been estranged for a long time. With her beloved brother and sister, Bim renews all her relationships in this impressive and sensitive time of realization. Time works as a preserver for her in this way. In the concluding episode of Clear Light of Day, Bim also attains the realization that her relationship with her brother can be compared with the harmonious bonding of Mulk guru's harsh voice and the sweet voice of young Mulk.

Bim's delusion disappears and by the clear light of day, she can see what her fault is. Her attitude changes towards Raja and she becomes repentant. Her alienation vanishes and she reminds of Eliot's line 'time the destroyer is time the preserver'. Ultimately, it is seen that time is eternal and Bim feels that relationship of time with eternity. She begins to sense her inadequate love for her 
siblings and she decides to seek forgiveness of Baba to whom she has spoken insensitively a little while ago. In this way, a new impetus is gained by Bim concerning her love for her sister Tara and her brothers, Raja and Baba. Thus, here, at this point, we come to observe how time has served as a preserver and Bim's love for her brothers and sister is not only revived in its full strength but is further increased.

The title of the novel, Clear Light of Day, refers to a passage in the fourth part of the novel in which Bim, who had always believed in the past, achieves the maturation now and begins to looks afresh in the 'clear light of day' that she felt only love and affection for them all:

"If there were hurts these gashes and wounds in her side that bled, then it was only because her love was imperfect and did not encompass them thoroughly enough and because it had flaws and inadequacies and did not extend to all equally" (P. 165).

\section{CONCLUSION}

Anita Desai's Clear Light of Day is a novel about laments for what was lost, but it does not stop merely at laments which echo and circle themselves endlessly; rather it is about the real significance of the past and it poses of how to live in the present that has been constructed from the past. The story of the Das family is told through each sister's memory and by beginning and ending in the present, the novel moves us backwards to understand where we are now; then again enters the past but then returns to the present. The storylines emerge and submerge to make the presence of the people who are felt even they are not seen. Bim lives in the boundaries between what is real and what is imagined but ultimately, she wakes up in the clear light of day to restore her relations with her brother, Raja and time the destroyer is indeed time the preserver. And it is present which has looked back and seen its reflection; Bim, finally, rests upon a silent gathering of insights undoubtedly and beautifully. She incorporates the world of the past and present and she is spiritually at ease at least for once in life:

"With her inner eye she saw how her own house and its particular history linked and contained her as well as her whole family with all their separate histories and experiences not binding them within some dead and airless cell but giving them the soil in which to send down their roots and food to make them grow and spread, reach out to new experiences and new lives, but always drawing from the same soil, the same secret darkness. That soil contained all time, past and future, in it. It was dark with time, rich with time. It was where her deepest self lived, and the deepest selves of her sister and brothers and all those who shared that time with her" (P. 278).

\section{REFERENCES}

[1] Desai, Anita. Clear Light of Day: Published by Penguin Random House India Pvt . Ltd, 2007, (All the Subsequent References taken from this edition).

[2] Jain, Jasbir. "Airing the Family Ghosts: Anita Desai's Clear Light of Day", Journal of Postcolonial Writing, Vol.24, No.2, 1984: 416-422.

[3] Prasad, Madhusudan: Anita Desai: The Novelist, New Horizon. Allahabad, 1981: P.122.

[4] O'Reilly, Christopher. Postcolonial Literature. UK: Cambridge University Press, 2001.

[5] Gupta, Santosh, Indian Women Novelists: Clear Light of Day, Gaziabad: Vimal Prakashan, 1984.

[6] T.S. Eliot, Collected Poems 1909-1962 (New York: Harcourt, Brace \& World, 1970), The Waste Land lines 36066; Eliot's note on the lines, pp. 74-75. For Eliot's intention in writing the poem, see the documents in The Waste Land: A Facsimile and Transcript of the Original Drafts including the Annotations of Ezra Pound ed. Valerie Eliot (New York: Harcourt, Brace, 1971). 